\title{
OCCUPATIONAL ASTHMA DUE TO TURPENTINE IN ART PAINTER — CASE REPORT
}

\section{WOJCIECH DUDEK ${ }^{1}$, TOMASZ WITTCZAK ${ }^{2}$, DOMINIKA ŚWIERCZYŃSKA-MACHURA ${ }^{1}$, JOLANTA WALUSIAK-SKORUPA ${ }^{2}$, and CEZARY PALCZYŃSKI ${ }^{1,2}$}

\author{
${ }^{1}$ Nofer Institute of Occupational Medicine and Environmental Health, Łódź, Poland \\ Centre of Occupational Allergy and Environmental Health \\ ${ }^{2}$ Nofer Institute of Occupational Medicine and Environmental Health, Łódź, Poland \\ Department of Occupational Diseases and Toxicology
}

\begin{abstract}
Turpentine is a fluid obtained by distillation of wood resins containing mixture of terpens. It can act as an irritant and sensitiser. Most common health problem among workers exposed to turpentine is contact dermatitis. Little is know about turpentine to cause type I hypersensitivity reaction. We present a case of a 27 -year old art painter using turpentine as a thinner for oil-based paints. She developed asthmatic reactions after 5 years of working with turpentine. A number of clinical procedures were performed, including clinical examination, routine laboratory tests, total serum IgE, skin prick tests to common aeroallergens, metal salts, oil-based paints and balsamic turpentine, resting spirometry test, histamine challenge, and a single-blind, placebo-controlled specific inhalation challenge with balsamic turpentine. Clinical findings and laboratory test results were normal but a significant bronchial hyperreactivity was found. During the specific challenge, dyspnoea and decreased forced expiratory volume $\left(\mathrm{FEV}_{1}\right)$ were observed in late phase of asthmatic reaction. An increased proportion of eosinophils in induced sputum could also be noted $24 \mathrm{~h}$ after the challenge. Positive clinical response to the specific challenge as well as the morphological changes found in induced sputum served as the basis for diagnosing occupational asthma. To our knowledge, this is the first well-documented case of turpentine-induced occupational asthma.
\end{abstract}

Key words:

Turpentine, Occupational asthma, Art painter

\section{INTRODUCTION}

Turpentine is a clear or yellowish highly flammable fluid obtained by steam distillation of wood resins, mainly from pine trees. It is a mixture of terpenes: alpha and beta pinenes, carene, camphene and dipentene [1]. Turpentine is used in different branches of industry as a solvent and as a source for organic synthesis. As a solvent, turpentine serve as a thinning component for oil-base paints, therefore, it is widely used by art painters. Exposure to turpentine may cause skin, eye and respiratory tract irritation and allergy due to type IV hypersensitivity reaction. Aplhapinene, delta-3-carene and turpentine peroxides are the main turpentine allergens [2]. There are many reports on contact dermatitis caused by turpentine exposure [1]. This type of allergy has been well described in painters, shoe repairers, home decorators and mechanics using impregnated soap [3-5] Little is know about type I hypersensitivity reactions caused by turpentine. In 1985 Hendy et al. presented a case report of a tool setter occupationally exposed to different oils, including pine oil, who developed asthmatic reaction due to pine oil [6].

\section{METHODS}

We present a case of a 27-year-old never-smoking art painter admitted to the Department of Occupational Diseases and Toxicology with a suspicion of occupational asthma. Patient had been working as an art painter for 7 years. She

Received: May 14, 2009. Accepted: June 3, 2009.

Address reprint request to W. Dudek, Department of Occupational Diseases, Nofer Institute of Occupational Medicine, św. Teresy 8, 91-348 Łódź, Poland (e-mail:wdudek@imp.lodz.pl). 
used balsamic turpentine as a thinner for oil-base paints. After 5 years of working as an art painter she developed recurrent non-productive cough and dyspnoea with wheezing. Symptoms tended to appear after 30-60 min of turpentine exposure. We performed a clinical examination, routine laboratory testing, chest X-ray, total serum IgE (Uni-CAP system Pharmacia Diagnostics, Uppsala, Sweden), skin prick tests (SPTs) to common aeroallergens (dust mites, tree and grass pollens, molds, feathers) (Allergopharma, Germany) and to $0.01 \%, 0.1 \%$ and $1 \%$ solutions of metal salts including nickel, chromium, cobalt, wolfram, vanadium, cadmium, zinc and manganese. We also performed prick-to-prick skin tests with non-diluted oil-based paints (PEBEO China, Talens Netherland) and balsamic turpentine (Blik, Poland). Resting spirometry and histamine challenge test were also performed (Mijnhardt spirometer, The Netherlands). After that, the patient was subjected to a single-blind, placebocontrolled work-like condition specific challenge tests - the first with placebo (linen oil), the second with oil-based paints and then with balsamic turpentine. There was 7 days period between the challenge tests. Subject painted $1 \mathrm{~m}^{2}$ wooden board with suspected material using art brush for $30 \mathrm{~min}$. Cellular composition of induced sputum was analysed. Induced sputum samples were collected before the provocation and $4 \mathrm{~h}$ and $24 \mathrm{~h}$ afterwards. The processing of induced sputum has been described elsewhere [7].

\section{RESULTS}

The clinical and laboratory findings (including chest x-ray) did not reveal any abnormalities. Total serum IgE was within normal limits $(78.05 \mathrm{kU} / \mathrm{l})$. SPTs to common aeroallergens, to $0.01 \%, 0.1 \%$ and $1 \%$ solutions of metal salts were negative. Prick-to-prick skin test to oil-based paints and turpentine were negative. On the admission to hospital, resting spirometry was normal: $\mathrm{FEV}_{1}=3.78$ 1 (105\% of predictive values), $\mathrm{FVC}=3.91$ ( $95 \%$ of predictive values). Histamine challenge revealed significant bronchial hyperreactivity $\left(\mathrm{PC}_{20}=1.38 \mathrm{mg} / \mathrm{ml}\right)$. The challenge tests with linen oil and oil-based paints did not reveal any abnormalities. There were no changes in rest spirometry values, no clinical symptoms of bronchial obstruction and we didn't observed any significant

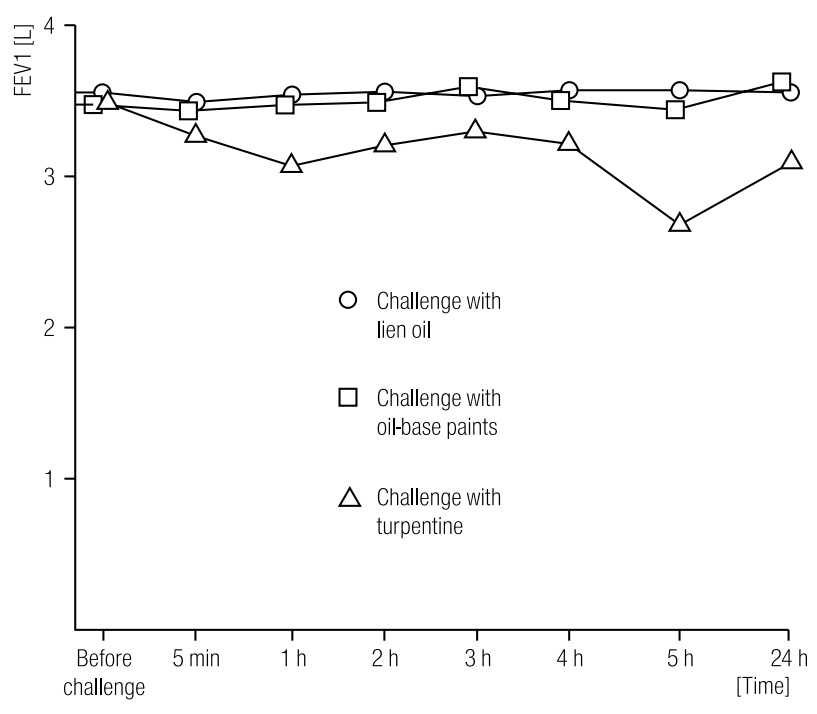

Fig. 1. Changes in $\mathrm{FEV}_{1}$ values after specific challenge with turpentine, oil-based paints and linen oil (placebo).

changes in eosinophil count in induced sputum after the exposure. On the day of specific challenge with turpentine, resting spirometry was as follow: $\mathrm{FEV}_{1}=3.66 \mathrm{l}(102 \%)$, $\mathrm{FVC}=3.831(93 \%)$. Five minutes after turpentine inhalation, subject reported tightness in the chest. One hour after turpentine exposure patient presented non-productive cough, mild dyspnoea and sore throat. Wheezing was observed during medical examination and resting spirometry revealed $10 \%$ drop in $\mathrm{FEV}_{1}$ value. At 10 hours after the challenge patient also reported mild dyspnoea and chest tightness. In PEFR monitoring, the drop in flow values down to $15 \%$ was observed in 1 st hour and between 5 th and 12th hour after challenge test. There was a mild drop in $\mathrm{FEV}_{1}$ values between 1 st and 4 th and a significant in 5 th hour after the challenge (down to 25\%) (Fig. 1). The increased number of eosinophils was observed in induced sputum $24 \mathrm{~h}$ after turpentine exposure (Table 1).

Table 1. Eosinophil count in induced sputum before, 4 and 24 hours after specific challenge with linen oil, oil-based paints, and balsamic turpentine

\begin{tabular}{lccc}
\hline \multirow{2}{*}{ Challenge with: } & \multicolumn{3}{c}{ Eosinophil count in induced sputum $(\%)$} \\
\cline { 2 - 4 } & $\begin{array}{c}\text { Before } \\
\text { challenge }\end{array}$ & $\begin{array}{c}\text { After } \\
\text { 4 hours }\end{array}$ & $\begin{array}{c}\text { After } \\
\text { 24 hours }\end{array}$ \\
\hline Turpentine & 4 & 4 & 16 \\
Oil-based paints & 5 & 5 & 4 \\
Linen oil & 4 & 5 & 5 \\
\hline
\end{tabular}




\section{DISCUSSION}

Turpentine is a well-known agent that can produce skin symptoms due to type IV hypersensitivity reaction [1]. Although there is a number of papers describing turpentine to cause contact dermatitis, there is no well documented case of type I hypersensitivity reaction due to this agent. The only case of asthma due to turpentine was presented by Hendy et al. in 1985 [6]. He performed comparative challenge test with turpentine alone and with cromoglycate administered prior to turpentine exposure. During the challenge test he obtained dual asthmatic reaction expressed by drop in $\mathrm{FEV}_{1}$ immediately after exposure and in 6th hour after. Cromoglycate administration before challenge prevented the patient from developing drop in $\mathrm{FEV}_{1}$ values. Thus, cromoglycate inhibition could be considered as a proof of turpentine to cause type I hypersensitivity reaction. Hendy et al. did not perform any assessment of cellular changes to confirm the specificity of the asthmatic reaction. In our case we managed to observe late asthmatic reaction with 25\% drop in $\mathrm{FEV}_{1}$ at 5 th hour of challenge. The specificity of asthmatic reaction was confirmed by significant increase in eosinophil count in induced sputum in 24th hour of challenge.

The diagnosis of turpentine-induced asthma in this patient was based on clinical response to specific challenge test involving late phase asthmatic reaction and the accompanying changes in induced sputum.

\section{REFERENCES}

1. Rudzki E, Berova N, Czernielewski A, Grzywa Z, Hegyi E, et al. Contact allergy to oil of turpentine: a 10-year retrospective view. Contact Dermatitis Research Group in Comecon Countries. Contact Dermatitis 1991;24(4):317-8.

2. Lear JT, Heagerty AH, Tan BB, Smith AG, English JS. Transient re-emergence of oil of turpentine allergy in the pottery industry. Contact Dermatitis 1996;35(3):169-72.

3. Hellerstrom S. Hypersensitivity tests in professional eczema, their applicability and sources of error. Acta Derm Venereol 1939;20:657.

4. Oleffe J. Epidemiologic, social and economical aspects of occupational dermatoses in Belgium. Arch Belg Dermatol 1973;29:93-104.

5. Cronin E. Contact dermatitis. 1st ed. Edinburgh: Churchill Livingstone; 1980. p. 797-805.

6. Hendy MS, Beattie BE, Burge PS. Occupational asthma due to an emulsified oil mist. Br J Ind Med 1985;42(1):51-4.

7. Krakowiak A, Krawczyk-Adamus P, Dudek W, Walusiak J, Pałczyński C.: Changes in cellular and biochemical profiles of induced sputum after allergen-induced asthmatic response: Method for studying occupational allergic airway inflammation. Int J Occup Med Environ Health 2005;18:27-33. 